\section{Burmannia championii Thwaites (Dioscoreales: Burmanniaceae), a new addition to the flora of Karnataka}

\section{Divakar K. Mesta ${ }^{1}$, Harsha V. Hegde ${ }^{2}$, Vinayak Upadhya ${ }^{3}$ \& Sanjiva D. Kholkute ${ }^{4}$}

${ }^{1}$ Smt. Parvatibai Chowgule College of Arts and Science, GogolMargao, Goa 403604, India

2,3,4 Regional Medical Research Centre (Indian Council of Medical Research), Nehru Nagar, Belgaum, Karnataka 590010, India Email: ${ }^{1}$ divakarmesta@rediffmail.com (corresponding author), ${ }^{2}$ harshavh@rediffmail.com, ${ }^{3}$ sirsivinayak@yahoo.com,

${ }^{4}$ sankhol@yahoo.com

Burmannia championii Thwaites is a small, white, filamentous, saprophytic herb belonging to the family Burmanniaceae. This has been recorded in an evergreen forest patch at Kathalekan near Jog Falls of Uttara Kannada (North Canara) District and at Karani of Shimoga District. Both the localities are in the central Western Ghats region in Karnataka. The voucher specimen of the collection has been deposited at the herbarium of Regional Medical Research Centre (ICMR), Belgaum (RMRC 00506) (Image 1). The identification has been confirmed by comparing with the authentic specimens housed at Madras Herbarium $(\mathrm{MH})$, Botanical Survey of India, Southern Circle, Coimbatore.

Date of publication (online): 26 January 2011

Date of publication (print): 26 January 2011

ISSN 0974-7907 (online) | 0974-7893 (print)

Editor: K. Gopalakrishna Bhat

Manuscript details:

Ms \# 02495

Received 29 June 2010

Final received 22 November 2010

Finally accepted 23 December 2010

Citation: Mesta, D.K., H.V. Hegde, V. Upadhya \& S.D. Kholkute (2011) Burmannia championii Thwaites (Dioscoreales: Burmanniaceae), a new addition to the flora of Karnataka. Journal of Threatened Taxa 3(1): 14651468

Copyright: (c) Divakar K. Mesta, Harsha V. Hegde, Vinayak Upadhya \& Sanjiva D. Kholkute 2011. Creative Commons Attribution 3.0 Unported License. JoTT allows unrestricted use of this article in any medium for non-profit purposes, reproduction and distribution by providing adequate credit to the authors and the source of publication.

Acknowledgements: Authors are thankful to National Medicinal Plant Board for the financial assistance, Joint Director, Botanical Survey of India, Southern Circle, Coimbatore $(\mathrm{MH})$ for permission to compare the specimen. DKM is thankful to the Principal, Smt. Parvatibai Chowgule College, Margoa for the support.

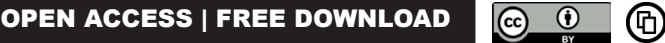

The family Burmanniaceae is represented by 17 genera and 125 species (Hajra 1988). They are

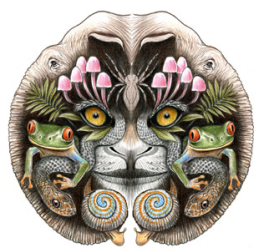
distributed in the tropics and sub tropics of both hemispheres. In India, it is represented by two genera (Burmannia and Haplothismia) and 10 species. The genus Burmannia comprises about 57 species (Shu 2010) distributed in tropics of both hemispheres, southern United States, southern Brazil, Bolivia, Mozambique, southern China, Southeast Asia, Japan and southern Australia. Nine species of Burmannia have been reported from India, of which three are endemic.

B. championii was reported earlier from Sri Lanka, Malayan peninsula, southern China and Japan (Hajra 1988). It was reported from Taiwan recently by Hsieh \& Ohashi (2000). Trimen \& Hooker (1984) mentioned this plant as endemic to Sri Lanka and reported it to be rare in moist low lands. In India, B. championii is recorded only from Andaman and Nicobar Islands (Balakrishnan 1976) and Kerala (Joseph et al. 1980). This report of the plant from Karnataka is after a gap of 30 years since its report from Kerala. The report gains importance as Balakrishnan et al. (1983) reported $B$. championii to be endangered in the Indian subcontinent.

The plant was observed in September 2008, as undergrowth in a swampy relic forest called Myristica swamp in Kathalekan (Uttara Kannada District) with a population of several individuals. It was growing amongst decaying litter and wet soil in the swamp and adjoining areas. The plant appeared as a small herb with terminal capitate inflorescence. The same plant was observed during the same field visit at Karani area of Shimoga District in an evergreen forest patch dominated by the trees of Poeciloneuron indicum Bedd. The detailed description of the plant with photographs (Images 2-5) are provided to enable its easy identification.

\section{Burmannia championii Thw.}

Enum. P1. Zeyl. 325. 1864; Hook. f., Fl. Brit. India 5: 666.1890; Jonker I.c. 38; Balakrishnan in Bull. Bot. Surv. India. 18(1-4): 230-231. 1976; Joseph, Ansari et Mohanan in Journ. Bombay Nat. Hist. Soc. 76: 552553. 1980.

Specimens examined: 19.ix.2008, Kathalekan, 

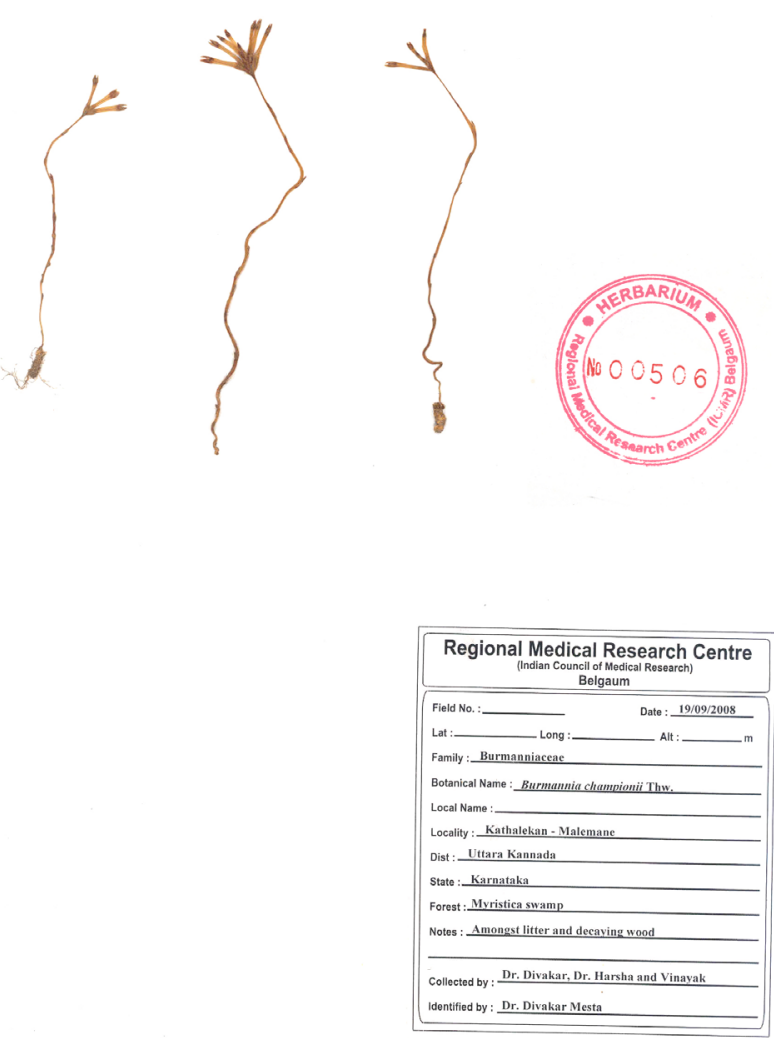

Image 1. Herbarium sheet of Burmannia championii with accession number RMRC 00506.

Uttara Kannada District, Karnataka, India, coll. Divakar K. Mesta, Harsha V. Hegde and Vinayak Upadhya, 506 (RMRC); 14.x.1979, Madampatty forest, Palghat District, Kerala, India, coll. N.C. Nair, $126012(\mathrm{MH})$.

It is a saprophytic herb with underground tuber of about $1 \mathrm{~cm}$ long and $0.6 \mathrm{~cm}$ diameter. Stem 7-15 $\mathrm{cm}$ high and $1 \mathrm{~mm}$ in diameter, simple, slender, white. Scales 2-4 mm long, lanciolate, spirally arranged; basal scales shorter. Bracts 3-4 mm long, acute. Inflorescence terminal, capitate or sub-capitate, 2-7-flowered. Flowers bisexual, tubular, wingless; up to $1.2 \mathrm{~cm}$ long, white. Outer perianth lobe up to $3 \mathrm{~mm}$, erect, acute; inner perianth lobe $1.5 \mathrm{~mm}$ long, minutely pubescent. Anthers sessile, halfway down the tube. Ovary to $3 \mathrm{~mm}$, oblong-ovoid; style thick, filiform; stigma 3-lobed, funnel shaped.

Flowering and fruiting: July-September, in the present localities (Kathalekan and Karani) these plants were in flower during September.

The family Burmanniaceae in general and $B$. championii in particular, are less studied as evidenced by the scanty literature. Hsieh \& Ohashi (2000) worked on SEM of the pollens from the Taiwan specimen. In the similar work, Chakrapani \& Raj (1971) reported the pollen morphology of 19 species of Burmannia, including $B$. championii. The phylogeny and evolution of Burmanniaceae was reported by Merckx et al. (2006) based on nuclear and mitochondrial data. However, they did not considered B. championii in their study. There are no reports either on chemical constituents or medicinal uses of $B$. championii. Even though, $B$. coelestis is reported to be used medicinally by Santals in India (Hajra 1988); details are not available. Hence avenues are open to work further on this species.

In addition to the earlier report on distribution of the plant in India, our report gives its further extension to the north of Kerala, forming a new addition to the flora of Karnataka. It also throws light on possible likelihood of its occurrence elsewhere in the evergreen forests of Western Ghats.

Note: During late monsoon, several individuals of B. championii shoot up from the subterranean tubers, especially in the wet, littered forest floor. The note on the $\mathrm{MH}$ herbarium sheet also indicates it as 'most common'. Even though it is a common herb in the ground layer of evergreen forests, it may have lost the attention of botanists due to its appearance like fungal fruiting body and its short life span.

\section{REFERENCES}

Balakrishnan, N.P. (1976). Burmannia championii Thw. An addition to the flora of the Andaman and Nicobar Islands. Bulletin of Botanical Survey of India 18(1-4): 230-231.

Balakrishnan, N.P. \& M.K.V. Rao (1983). The Dwindling Plant Species of Andaman and Nicobar Isalnds, pp. 186201. In: Jain, S.K. \& R.R. Rao (eds.). An Assessment of Threatened Plants of India. Botanical Survey of India, Howrah.

Chakrapani, P. \& B. Raj (1971). Pollen Morphological Studies in the Burmanniaceae. Grana 11(3): 164-179.

Hajra, P.K. (1988). Burmaniaceae, p. 9. In: Nayar, M.P., K. Thothathri \& M. Sanjappa (eds.). Fascicles of Flora of India, Fascicle 19. Botanical Survey of India, Kolkata.

Hooker, J.D. (1890). The Flora of British India, Vol. 5. L. Reeve and Co., London, 666pp.

Hsieh, T.H. \& H. Ohashi (2000). A new record of Burmannia championii Thwaites (Burmanniaceae) in Taiwan. Taiwania 45 (4): 346-350.

Joseph, J., R. Ansari \& C.N. Mohanan (1980). Burmannia championii Thw. An addition to the flora of south India. Journal of the Bombay Natural History Society 76: 552-553. 


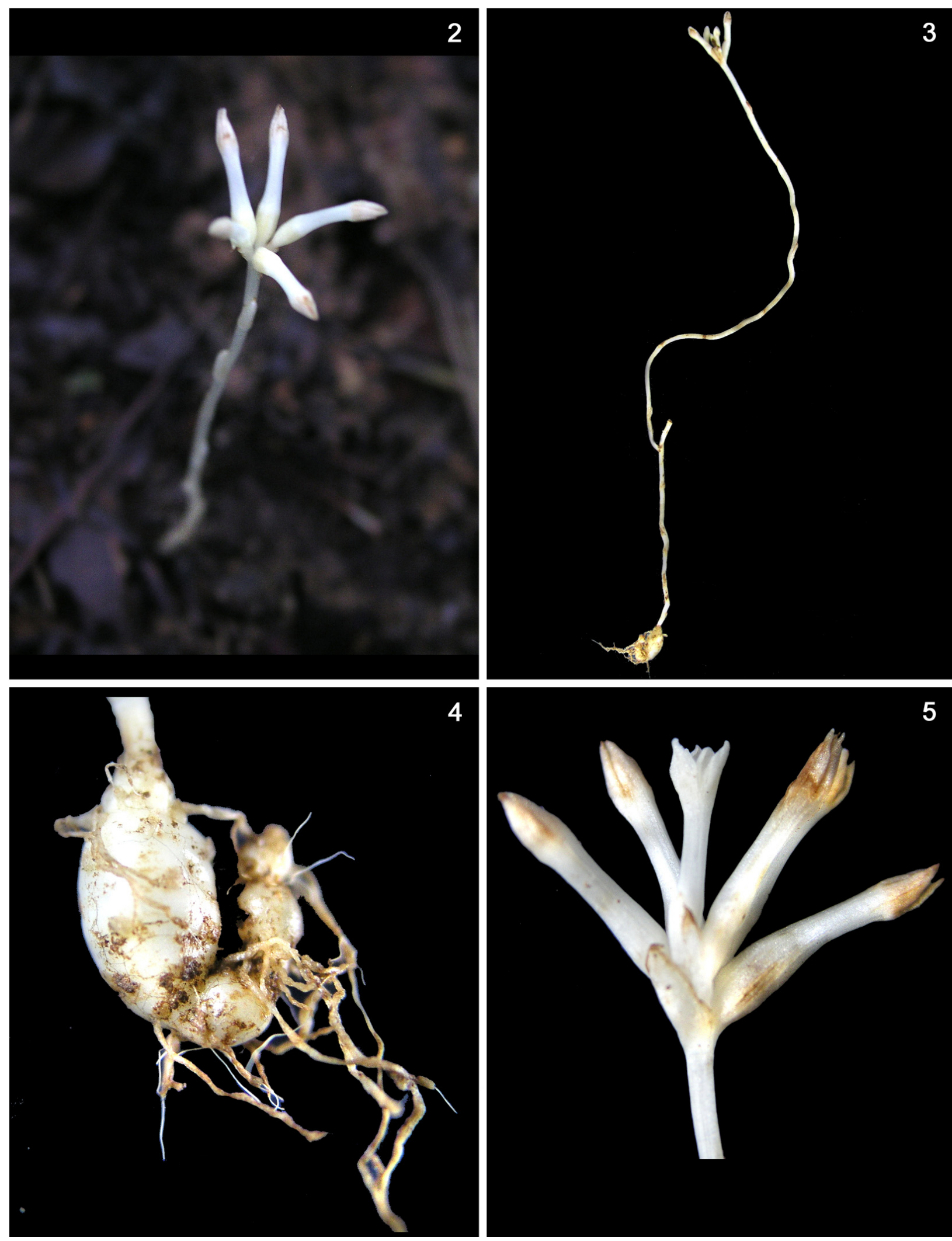

Image 2-5. Burmannia championii Thw.

2 - Habit; 3 - Plant with intact tuber; 4 - Tuber; 5 - Inflorescence 
Merckx, V., P. Schols, H.M. Van De Kamer, P. Maas, S. Huysmans \& E. Smets (2006). Phylogeny and evolution of Burmanniaceae (Dioscoreales) based on nuclear and mitochondrial data. American Journal of Botany 93(11): 1684-1698.

Shu, S.Y.Z. (2010). Burmanniaceae in Flora of China 23: 121-123. http://flora.huh.harvard.edu/china/PDF/PDF23/ Burmannia.pdf downloaded on 13 January 2011.

Trimen, H. \& J.D. Hooker (1984). A Handbook to The Flora of Ceylon. Bishan Singh Mahendra Pal Singh, Dehra Dun, $131 \mathrm{pp}$. 